AMERICAN CULTURE SERIES I. Basic source materials for the study of American culture and civilisation. From the EPISTOLA of Columbus, 1493, to 1800 comprised of 26 reels of microfilm containing 253 titles and arranged under seventeen bibliographical headings.

AMERICAN CULTURE SERIES II. Begins with books printed in 1801. Arranged by broad subject categories containing nearly 6,000 titles to 1906 . Available on an annual subscription basis.

AMERICAN PROSE FICTION. Will include over 11,000 separate works of fiction written by American authors 1774-1900. Available on an annual subscription basis.

AMERICAN PERIODICAL SERIES 1. A complete unit of 91 Titles on 33 reels $1741-1800$.

AMERICAN PERIODICAL SERIES II. A continuation of APS I and available in series-years $1800-1910$.

AMERICAN PERIODICAL SERIES III. Running concurrent with APS II, this special series includes separate titles covering the Civil War and Reconstruction eras. Comprehensive range of subjects is covered as in APS II.

FURTHER DETAILS ARE IN OUR BROCHURE.

UNIVERSITY MICROFILMS LIMITED

A XEROX COMPANY

Penn 3844

St. Johns Road, Tylers Green, Bucks

Telex : 83536

AM.ST.--back 


\section{BRITISH ASSOCIATION FOR AMERICAN STUDIES}

This Assoriation was founded in 1955 to promote the study of the United States within the United Kingdom. It welcomes applications for membership from people interested in the history, society, government and politics, economics, geography, literature and thought of the United States. It publishes a Newsletter twice yearly, holds an Annual Conference, and provides other services for its members from time to time. Enquiries concerning current subscription rates and applications for membership should be addressed to the Secretary, Dr Charlotte Erickson, London School of Economics, Houghton Street, Aldwych, London,
$\mathrm{WC}_{2} \mathrm{~A} 2 \mathrm{AE}$.

\section{NOTES FOR CONTRIBUTORS}

I. All contributions and editorial correspondence should be sent to: The Editor, Journal of American Studies, Department of American Studies, The University, Manchester Mr3 9PL, England.

2. Articles should generally contain about 5000 words. Longer or shorter articles, or articles in two or more parts, may be accepted by arrangement
with the Editor.

3. Submission of an article is taken to imply that it has not previously been published, or is not being considered for publication elsewhere.

4. Contributions should be clearly typed in double spacing, preferably on $\mathrm{A}_{4}$ paper, with a wide left-hand margin. Diagrams and maps may be included
by arrangement with the Editor.

5. Footnotes should be used sparingly: in general, to give sources of direct quotations, references to main authorities on disputable questions, and evidence relied on for a new or unusual conclusion. They should be numbered in one sequence throughout the article, and should preferably be typed in double spacing at the end of the article.

6. Contributors should keep one copy of the typescript for correcting proofs.

7. Notes intended for the Editor or printer should be on a separate sheet.

8. First proofs may be read and corrected by contributors provided that they can give the Editor an address through which they can be reached without delay and can guarantee to return the corrected proofs to the Editor, by airmail where necessary, within ten days of receiving them.

9. Correction should be kept to an absolute minimum. It should be confined to errors of the typist or printer unless the Editor authorizes otherwise.

10. Contributors of articles and review articles receive 25 free separates. Extra copies may be ordered according to the scale of charges.

II. Contributors need not be members of the British Association for American Studies. Unsolicited typescripts can only be returned to overseas contributors who send International Reply Coupons (not postage stamps).

12. Contributors of accepted articles will be asked to assign their copyrights, on certain conditions, to Cambridge University Press, to help protect their material, particularly in the U.S.A. 


\section{Volume 6 Number 2 August 1972}

\section{JOURNAL OF AMERICAN STUDIES}

page 29 Roвевt M. Bliss

A Secular Revival:

Puritanism in Connecticut, $1675^{-1708}$

153 R. A. BurCHELL

Did the Irish and German Voters Desert

the Democrats in 1920?

A Tentative Statistical Answer

165 Allen Weinstein

The Symbolism of Subversion:

Notes on Some Cold War Icons

181 A. B. ENGLAND

Robin Molineux and the Young Ben Franklin:

a Reconsideration

i 89 John C. Davies

'Which is the American?' :

Themes, Techniques, and Meaning in

William Carlos Williams's Three Novels

201 JoHN C. HIRSH

The Imagery of Dedication in Robert Lowell's

'For the Union Dead'

BOOR REVIEWS

CAMBRIDGE UNIVERSITY PRESS

Bentley House, 200 Euston Road, London NWI $2 \mathrm{DB}$

American Branch: 32 East 57th Street, New York, N.Y. 10022

$£ 2.00 \mathrm{net} ; \$ 6.50$ in U.S.A. Subscription price $£_{4} .00$ net; $\$ 12.50$ in U.S.A.

Printed in Great Britain by The Eastern Press Lid., London and Reading https://doi.org/10.1017/S0021875800001262 Published online by Cambridge University Press 